\title{
Forest property insurance: an application to Portuguese woodlands
}

\section{António Cipriano Pinheiro*}

Departamento de Economia, Universidade de Évora, Largo dos Colegiais, 2, 7000-803 Évora, Portugal

E-mail: acap@uevora.pt

*Corresponding author

\section{Nuno de Almeida Ribeiro}

Departamento de Fitotecnia, Universidade de Évora, Largo dos Colegiais, 2, 7000-803 Évora, Portugal

E-mail: nribeiro@uevora.pt

\begin{abstract}
Fire is the biggest forest hazard, especially in Mediterranean climate countries, leading to desertification and collapse (Naveh, 2007). Wildfire is among the most dramatic threats to forests (Goldammer, 2004). In many countries, it is not easy to find companies that want to insure forests stands. This can be explained by the following reasons. Firstly, in many countries, forest insurance is not mandatory; so many farmers do not make it. Secondly, insurance companies need to have models based on desegregated and reliable data to estimate the probability of fire occurrences. Finally, it is very difficult for the insurer to estimate the real value of the stands because their values vary with the species, the stand age and market prices. The main objective of this paper is to present simple models that help to estimate 'fair' insurance risk premiums, contributing, in this way, to make forest business more appealing and sustainable.
\end{abstract}

Keywords: forest fire; insurance; risk premium; forest property insurance.

Reference to this paper should be made as follows: Pinheiro, A.C. and Ribeiro, N.A. (2013) 'Forest property insurance: an application to Portuguese woodlands', Int. J. Sustainable Society, Vol. 5, No. 3, pp.284-295.

Biographical notes: António Cipriano Pinheiro got his $\mathrm{PhD}$ in Agricultural Economics from Iowa State University. He is Full Professor at the University of Evora. He teaches undergraduate and graduate courses in agricultural economics, rural development and quantitative methods. For several periods, he has been an International Consultant for the Inter-American Institute of Cooperation for Agriculture in Brazil. He has been an independent Project Appraiser for research in the areas of Common Agricultural Policy (CAP), Management of Agricultural Resources and Management of Living Resources, for projects financed by the European Commission. His research areas of interest include CAP and natural resources, mainly water and forests. 
Nuno de Almeida Ribeiro is a Researcher at the Institute for Mediterranean Agrarian Sciences (ICAM) and Professor at the University of Évora, Portugal (Department of Crop Science). He has conducted research on tree growth and yield modelling, mainly in pure and mixed cork oak stands. He has developed a single tree spatial growth simulator for cork oak (CORKFITS) and is currently developing an ecological-based decision support system (ECCORK) for aid in management decisions for cork oak stands.

\section{Introduction}

Every year, millions of hectares of forest are burned and many forest owners who relied on incomes from their forests go bankrupt. Even when they receive government subsidies, these are very small to face their losses. To avoid this situation, it was expected that farmers took forest risk insurance!

Unlike the risk of many others disasters, that are the business of insurance companies, forest risk insurance against fire is still little frequent in many European countries, mainly in the Mediterranean area. In Portugal, it is extremely difficult to make forest fire insurance contracts. Some insurance companies just do not accept this type of risk insurance; others only accept this type of contracts to their former clients, ask lots of questions (including the insurance value of the forest property (IVFP) and say that for risk premium computation, only consider $70 \%$ of the declared value). These companies, very often, after consulting their technical support services end up just saying 'we cannot accept this type of risk'. Finally, some other companies only ask the name of stand species, the area and location of the property. They ascribe a very low value to the forest property. The premium rates are computed as something like $3 \%$ of that value. Under these circumstances, only a minority of private owners makes insurance contracts.

The director of Australian Forest Growers, Cummine (2000) wrote:

"it can be difficult for an individual grower to obtain forestry insurance cover. Forestry insurance is very specialized, and cover is provided by only a small number of underwriters. Even if an individual grower succeeded in taking out insurance, the premium rates could be very high."

In France, De Saint-Vincent (2000) estimates that out of 15 million ha of forest, only about 800,000 ha are insured. Forest risk insurance in Germany is at very beginning (Holecy and Hanewinkel, 2004).

It is long since that the luck insurance in forest has been recognised. In 1935, Shepard referred that the risk to private capital in forestry in comparison with probable returns generally remains so great that insurance would aid in interesting the investor in the forest business (Shepard, 1935).

The question is: why insurance companies are not as competitive in forest fire insurance contracts as they are in other branches of activities, such as car accidents or healthcare? There are several reasons, but we believe that the most important are:

1 the lack of deep empirical forest knowledge to estimate the expected value of forest stands

2 the lack of empirical investigation to quantify forest fire hazards for specific species and sites. 
The objective of this paper is to present a simple methodology that can help insurance companies and farmers to find out the fair insurance premium (IP) for forest fire, contributing, in this way, to lower the IPs and, consequently, to increase the number of forestry farmers that will use them.

\section{The Mediterranean forest - the case study}

\subsection{Mediterranean climate}

The Mediterranean climate has very dry and very hot summers (two or three months without any rain), cold and rainy winters. As it can be seen from Figure 1 there is a long period of water stress coincident with summer. During summer season (June-August) the temperatures are very high and there is almost no rain, so there is a high water deficit leading to a great plant water stress. These are the ideal conditions for fire.

Table 1 presents the number of fire events and the burned areas for the period of 2001-2009. If we have in mind that the Portuguese forest area is around 3 million ha, so, every year, the fire destroys about $3.5 \%$ of it. In economic terms it represents a big loss, not only because of the value of the trees that are burned, but also because of the amount of resources (human and material) that are needed to fight the fire.

The average burned area for the considered period was $3.47 \%$ for forest stand area and $3.68 \%$ for brushwood area or $7.15 \%$ of the total forest area.

During the period of 1991-2001, there were 261,424 fires that burned 1,158,278 (3.35\%) ha of forest stands (UNECE-FAO, 2002). This value is almost identical to the one we estimated above for the period 2001-2009.

Figure 1 Mediterranean climate ombrothermic diagram

$$
\begin{aligned}
& \text { Évora (Mitra), Portugal: } 200 \mathrm{~m} ; 15.5^{\circ} \mathrm{C} ; 664.6 \mathrm{~mm} \\
& \text { Average values for the period : } 1951-1980
\end{aligned}
$$

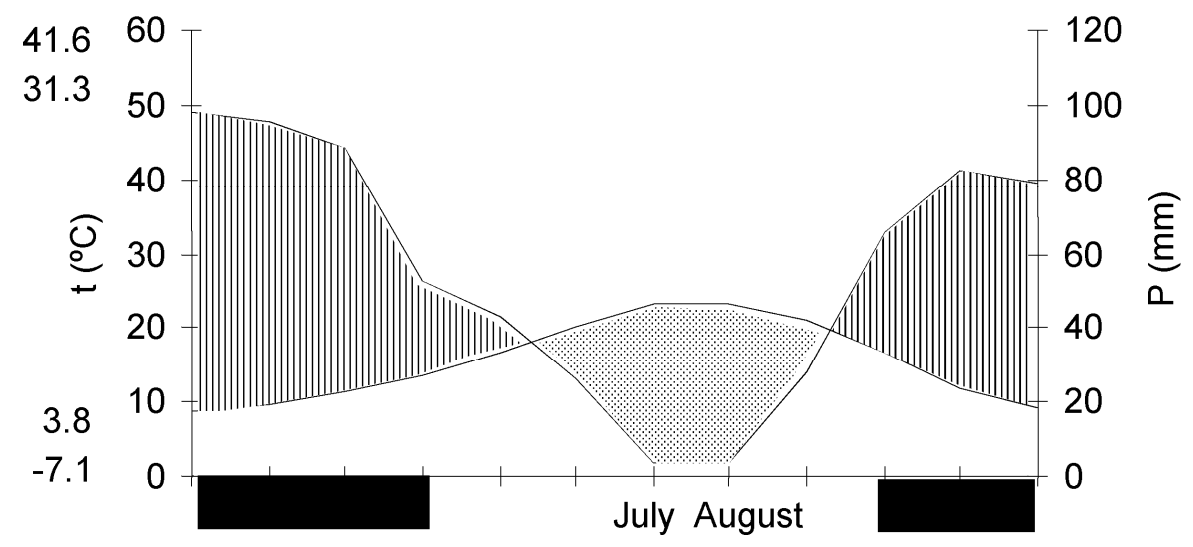


Forest property insurance: an application to Portuguese woodlands

Table 1 Number of fire events and burned areas for period 2001-2009

\begin{tabular}{lcccccc}
\hline & Number of & \multicolumn{2}{c}{ Burned area (ha) } & Total burned & \multicolumn{2}{c}{ Burned area probability (\%) } \\
\cline { 3 - 4 } Year & fire events & Forest stand & Brushwood & area & Forest stand & Brushwood \\
\hline 2001 & 26,723 & 45,160 & 66,206 & 111,366 & 2.58 & 3.05 \\
2002 & 26,358 & 64,720 & 58,539 & 123,259 & 2.43 & 2.85 \\
2003 & 26,135 & 286,181 & 138,889 & 425,070 & 9.68 & 6.65 \\
2004 & 21,849 & 93,571 & 71,871 & 165,442 & 2.63 & 3.05 \\
2005 & 35,548 & 211,915 & 125,168 & 337,083 & 10.59 & 7.46 \\
2006 & 19,596 & 35,816 & 38,742 & 74,558 & 1.59 & 2.48 \\
2007 & 18,912 & 9,285 & 30,939 & 40,224 & 0.38 & 2.33 \\
2008 & 13,588 & 5,079 & 16,532 & 21,611 & 0.25 & 1.05 \\
2009 & 23,903 & 22,624 & 83,895 & 106,519 & 1.10 & 4.19 \\
\hline
\end{tabular}

Source: Autoridade Florestal Nacional.

\subsection{Specificities of 'montado' woodlands}

The agro-silvopastoral system 'montado' dominates the landscape of the south-western Iberian Peninsula, which occupies $\sim 3.1$ million ha of woodland in Spain (Díaz et al., 1997) and 1.2 million ha in Portugal (DGF-IFN, 2001). The forest system 'montado' is mostly dominated by Mediterranean evergreen oaks such as cork oak (Quercus suber L.) and holm oak (Quercus rotundifolia). The 'montado' production system management aims the maintenance of a balanced sustainable land use to cope with the Mediterranean climate variability. The 'montado' stands are managed in agro-silvopasture systems of which sustainability depends on balanced relations between their components:

1 forest component managed for continuous crown cover to sustainably produce cork, acorn, wood, firewood and support productions of natural pasture, mushrooms, honey, natural habitat for hunting species, etc.

2 pasture component based on an extensive livestock, with the animals feeding directly on leaves, acorns and grass (from natural/artificial, temporary/permanent pasture systems) and complemented with stored cereal culture products that, in some areas, is grown in long rotations (Campos et al., 2001; Ribeiro et al., 2004, 2006).

The agro-silvopastoral system 'montado' ownership is characterised in Portugal by large private estates (on average above 100 ha per farm) and multi-functional production of commercial and non-commercial goods and services. In addition to these traditional commercial uses, there are other benefits that are of growing interest to the society such as wildlife habitat, private amenities, public recreation opportunities, carbon storage and quality water production (Campos and Caparrós, 2006). 'Montado' forest landscapes represent one of the best Mediterranean examples of the development of the multifunctional role of forests maintained over thousands of years. In these landscapes, forest areas with a high conservation value alternate with multi-purpose farmland systems. ${ }^{1}$

In Portugal, forest occupies 3.4 million ha of which $85 \%$ is owned by privates, $3 \%$ is owned by state and the remaining $12 \%$ is owned by communities (Coelho, 2003). 
Although a large percentage of the area is private, the management is subjected to public rules imposed by national policies, such as:

1 Ministry of Agriculture and Forest (forest regime and protected species law)

2 Ministry of Environment (protected areas, Natura 2000 net and National Parks).

Cork oak forest occupies $\sim 700,000$ ha of land, which makes Portugal the most important cork producer of the world (DGF-IFN, 2001).

Although cork oak fruits can be used to feed animals and some wood can be sold, the main source of income of this forest is cork. There are varying degrees of quality and cork undergoes a strict quality selection process that determines its final use. The best quality cork is selected for bottle stoppers (Pinheiro et al., 2008).

There are several threats to this forest production system, mainly economic (the decreasing cork price due to the increasing number of stopper substitutes, the increasing costs of management and the decreasing rural population) and environmental (climate change that increases the drought period and, consequently, the fire risk and water stressrelated menaces to the trees). On the one hand, the shrub system control that guarantees 'montado' sustainability is more expensive than other mostly used by farmers and reduces the income from animal rising. On the other hand, fire is also a great environmental threat.

\subsection{Database for fire probability estimation}

Fire is mainly caused by man's voluntary or involuntary actions. Only a very small percentage of fire events have origin in natural hazards. As it was said before, in Mediterranean regions, during summer, there are very favourable conditions for fire, so any human negligence can cause a fire. Therefore, to change human hazardous habits, human education can play an important role in decreasing the number of fire events.

Like many other events, fire is the kind of hazard almost impossible to foresee. However, if everything remains constant, the past experience is the best source of information one can use to estimate the probability of another similar event to happen (even considering that human habits are changing, they change very slowly).

In this way, to estimate the probability that a fire happens in a given region (e.g. in a municipality), with $A$ hectares of area, we use a temporal series and estimate the empirical probability of fire in that municipality by:

$$
P_{\mathrm{f}, i}=\frac{n_{i}}{N}
$$

$P_{\mathrm{f}, i}$ is the annual probability of fire in municipality $i, n_{i}$ is the number of years with registered fire occurrences and $N$ is the number of years with recorded events, the length of the time series.

The annual average burned area can be estimated by:

$$
\overline{\mathrm{BA}}_{i}=\frac{\sum_{j}^{N} X_{j, i}}{N}
$$


where $\overline{\mathrm{BA}_{i}}$ is the annual average burned area in region $i$, and $X_{j, i}$ is the burned area in year $j$ and region $i$.

So, the expected burned area in region $i, \mathrm{EBA}_{i}$, will be estimated by:

$$
\mathrm{EBA}_{i}=P_{\mathrm{f}, i} \cdot \overline{\mathrm{BA}_{i}}
$$

The empirical probability of fire for different class areas can also be estimated. Supposing, we have five forest class areas and for each class the frequency of fire events during the last $N$ years have been registered. Table 2 represents these hypothetical data.

If $n=n_{1}+n_{2}+\ldots+n_{5}$.

If a fire happens, the relative frequency of burning $a_{k}$

$$
\mathrm{RF}, a_{k}=\frac{\sum_{v=k}^{5} n_{v}}{n} \text { and } a_{1}<a_{2}<a_{3}<a_{4}<a_{5}
$$

So, the probability of specific farm of $a_{k}$ hectares of forest being burned in region $I$ with $A$ hectares can be estimated by:

$$
P_{\mathrm{f}}, a_{k}=P_{\mathrm{f}, i} \cdot \mathrm{RF}, a_{k} \cdot \frac{a_{k}}{A}
$$

where $a_{k} / A$ represents the number of forest farms of area $a_{k}$ in the region of area $A$.

Table 2 Forest areas and number of fire events

\begin{tabular}{lc}
\hline Forest areas size classes & Number of fire events \\
\hline$a_{1}$ & $n_{1}$ \\
$a_{2}$ & $n_{2}$ \\
$a_{3}$ & $n_{3}$ \\
$a_{4}$ & $n_{4}$ \\
$a_{5}$ & $n_{5}$ \\
\hline
\end{tabular}

\section{Valuation of the forest property for insurance}

\subsection{Some concepts and definitions}

Before presenting the methodology to estimate the value of the forest property, some definitions are presented to make the text more understandable. So, similar to Holecy and Hanewinkel (2004), we define:

Expected physical loss (EPL): EPL is equal to the number of hectares of the forest multiplied by the probability of fire.

Financial risk (FR): FR is an expected loss expressed in money terms, it is equal to the value of the property multiplied by the probability of fire occurrence.

Insurance premium (IP): IP is an expression of a FR in terms of money to compensate an entrepreneurial individual FR. The IP can be dived into the $F R$ of a forest owner which is equal to the net IP and the FR of an insurer that we call risk premium. 
Gross insurance premium (GIP): GIP is equal to the sum of the net IP and risk premium (Cipra, 1994).

Given that forests are subjected to disasters, i.e. it runs the hazard of being burned; the social role of insurance companies is to divide the loss of one or several forest owners among all insured forest farmers. So, the object to be insured (the insurance value) is the loss that a forest owners will have in case of fire.

\subsection{The forest stand expected value}

To estimate the loss of a forest farmer, it is necessary to determine the following three different parameters (Holecy and Hanewinkel, 2004):

1 the forest stand expectation value, $\operatorname{FSEV}(t)$, at forest age $t$ and the related soil expectation value, $\operatorname{SEV}(T)$, at the end of the rotation $T$

2 the salvage value, $\operatorname{SV}(t)$, of forest stand in case of fire

3 the risk-free soil expectation value, $\operatorname{RFSEV}(T)$.

The loss that a forest property suffers and the insurance value of a forest property at age $t$, $\operatorname{IVFP}(t)$, can be estimated by:

$$
\operatorname{IVFP}(t)=\operatorname{FSEV}(t)-\operatorname{SV}(t)+\operatorname{SEV}(T)-\operatorname{RFSEV}(T)
$$

or

$$
\operatorname{IVFP}(t)=\operatorname{FSEV}(t)-\operatorname{SV}(t)+\operatorname{RPSEV}(T)
$$

In expression (4), RPSEV $(T)$ represents the risk premium on the $\operatorname{SEV}(T)$.

To estimate the $\operatorname{FSEV}(t)$, we can use Faustmann formula as follows:

$$
\operatorname{FSEV}(t)=\frac{\sum_{j=t}^{T}\left(R_{j}-C_{j}\right)(1+r)^{T-j}+\operatorname{SEV}(T)}{(1+r)^{T-t}}-\operatorname{SEV}(T)
$$

where $R_{j}$ and $C_{j}$ refer to the nominal values of expected revenues and costs, respectively, occurred during period of $j \operatorname{SEV}(T)$ is the soil expectation value of the investment calculated based on the net present value, $\operatorname{NPV}(T)$, on time $T$ and $r$ is the rate of discount.

\section{Insurance premiums}

IPs provide both the forest owner and the insurer with the information about the risk of fire during an average year. But the risk is not the same for both.

Assuming that fire insurance is compulsory for all forestry farms in region $i$, with area $A$, the expected damage caused by a fire for an insurance company is not the same for a farmer. The financial risk of an insurer, per hectare, $\operatorname{FRI}(t)$, can be estimated by:

$$
\operatorname{FRI}(t)=\frac{\operatorname{EBA}_{i} \cdot \operatorname{FSEV}(t)}{A}
$$


For the owner of a forest of area $a_{k}$ hectares, the fire can be small a one, burning only $a_{1}$ hectares or any other area between $a_{1}$ and $a_{k}$ or an area grater then $a_{k}$. So, the expected risk depends upon the frequency of fire for his farm size. The insurance premium that a owner, $\operatorname{IPO}(t)$ of a forest of size $k$, is willing to pay varies from a maximum of

$$
\operatorname{IPO}(t)=P_{\mathrm{f}}, a_{1} \cdot \operatorname{FSEV}(t)
$$

to a minimum of

$$
\operatorname{IPO}(t)=P_{\mathrm{f}}, a_{k} \cdot \operatorname{FSEV}(t)
$$

To make this explanation more understandable, let us consider an easy hypothetical example. Assume that we have data, for the last 100 years, about fires of one forest homogeneous region of 4,000 ha. Columns 1 and 2 of Table 3 present the primary data, farm size class interval and number of fires occurred in the last 100 years. Column 3 is the averaged burned area per farm size (the estimations were made considering the middle point of the class area). Column 4 is the relative frequency of fires burning a area equal or smaller then $a_{k}\left(\mathrm{RF}, a_{k}\right)$. Column 5 shows the probability of burning an area as large as $a_{k}$. Assuming that FSEV(t) is equal to 5,000€ ha ${ }^{-1}$, column 6 shows the expected loss ha ${ }^{-1}$ for farmer.

As we can see from the last column of Table 3, the expected loss, per hectare, for the farmer, varies considerably according to farmer's area.

Let us estimate the FRI, assuming that insurance is compulsory for the entire region of 4,000 ha. From Equation (6)

$$
\begin{aligned}
& \operatorname{FRI}(t)=\frac{\mathrm{EBA}_{i} \cdot \operatorname{FSEV}(t)}{A} \\
& \mathrm{EBA}_{i}=\frac{\left(\frac{48}{100}\right) * 2,160}{48}=21.6 \mathrm{ha} \\
& \operatorname{FRI}(t)=\frac{(21.6 * 5,000 €)}{4,000}=27.00 \mathrm{Eha}^{-1}
\end{aligned}
$$

As it is expected, the IP of the company is much higher than the expected private farmer loss. However, a farmer must think that if has no insurance and a fire occurs in his forest, he will have a loss of 5,000€ ha ${ }^{-1}$ !

Table 3 Example with hypothetical data

\begin{tabular}{lccccc}
\hline $\begin{array}{l}\text { Farm size class } \\
\text { interval (ha) }\end{array}$ & $\begin{array}{c}\text { Number of fire } \\
\text { events }\end{array}$ & $\begin{array}{c}\text { Average burned } \\
\text { area }(\mathrm{ha})\end{array}$ & $R F, a_{k}$ & $P_{f}, a_{k}$ & $\begin{array}{c}\text { Farm expected } \\
\text { loss ha }\end{array}$ \\
\hline$<20$ & 16 & 160 & 0.480 & 0.00120 & 6.00 \\
$20-40$ & 10 & 300 & 0.320 & 0.00240 & 12.00 \\
$40-60$ & 6 & 300 & 0.220 & 0.00275 & 13.75 \\
$60-80$ & 4 & 280 & 0.160 & 0.00280 & 14.00 \\
$80-100$ & 10 & 900 & 0.120 & 0.00270 & 13.50 \\
$>100$ & 2 & 220 & 0.020 & 0.00055 & 2.75 \\
& Total $=48$ & Total $=2,160$ & & & \\
\hline
\end{tabular}




\section{Application to 'montado' woodlands}

The cash flow of common management cork oak production is summarised in Table 4. The only sources of revenue considered are cork and cattle production. On the cost side, only infesting control and cork stripping off costs are taken into account.

It is assumed that after 108 years new cork trees are planted.

Following the methodology above explained and considering interest rate of 3\% per year $(r=0.03)$.

Table 5 shows that the $\operatorname{FSEV}(t)$ and, consequently, all values derived from it vary not only with the age of cork oak trees, but also with the year of striping off the cork. The $\operatorname{FSEV}(t)$ increases up to the first cork stripping off, after that it remains almost constant between the ages of 24 and 72 years. After that it decreases sharply.

Based on fire occurrences and burned areas of Table 3, the cork oak data of Table 4 and considering an area $(A)$ of 4,000 ha, we estimate the values of Table 6 .

Table 6 shows that the insurer FR is much bigger than individual farmer's. This proves what above has been said that if forest insurance was mandatory, the insurance company could dilute (to share) the fire risk among a large farm group, demanding from each one a much smaller IP, which incentives the implementation of a system of risk insurance against fire. The FRI, per hectare, depends upon the area $(A)$ considered. As large as that area is, the smaller the FR will be.

Table 4 Summary of the assumptions used for cork oak investment

\begin{tabular}{llc}
\hline Year $(s)$ & \multicolumn{1}{c}{ Activity } & Cost/benefit $\left(€ \mathrm{ha}^{-1}\right)$ \\
\hline 0 & Planting cost & $-1,500$ \\
$3-108$ (every third year) & Infesting control by shrub cutting & -90 \\
$3-108$ (every third year) & Cattle revenue & 45 \\
27 & Cork production, $\sim 1,000 \mathrm{~kg}$ & $1,500^{\mathrm{a}}$ \\
$36-100$ (every ninth year) & Cork production, $\sim 1,600 \mathrm{~kg}$ & 4,000 \\
27 & Stripping off cost $\left(0.23 € \mathrm{~kg}^{-1}\right)$ & -230 \\
$36-108$ (every ninth year) & Stripping off cost $\left(0.23 € \mathrm{~kg}^{-1}\right)$ & -368 \\
\hline
\end{tabular}

${ }^{\mathrm{a}}$ The revenue from cork selling depends on its quality. It is assumed that the price ranges from 1.33 to $4.00 € \mathrm{~kg}^{-1}$. In this study, we consider price of $1.5 € \mathrm{~kg}^{-1}$ for the first stripping and $2.5 € \mathrm{~kg}^{-1}$ for the following ones.

Table 5 Estimation of the insurance forest value, per hectare, for different ages of cork oak trees

\begin{tabular}{lrrrrr}
\hline Age $(t)$ & $S E V(t)$ & $F S E V(t)$ & $S V(t)$ & RFSEV $(T)$ & IVFP(t) \\
\hline 0 & - & - & - & $3,267.86$ & $3,267.86$ \\
12 & $-5,508.40$ & $3,846.18$ & 70.00 & $3,267.86$ & $7,044.04$ \\
24 & $-3,437.67$ & $7,255.43$ & 190.00 & $3,267.86$ & $10,333.29$ \\
36 & -10.76 & $10,459.14$ & 310.00 & $3,267.86$ & $13,417.00$ \\
48 & $1,210.40$ & $7,536.79$ & 430.00 & $3,267.86$ & $10,374.65$ \\
60 & $1,949.39$ & $8,180.56$ & 550.00 & $3,267.86$ & $10,898.41$ \\
72 & $2,940.51$ & $8,696.28$ & 670.00 & $3,267.86$ & $11,294.14$ \\
84 & $3,169.20$ & $5,023.36$ & 790.00 & $3,267.86$ & $7,501.22$ \\
96 & $3,342.19$ & $4,597.01$ & 910.00 & $3,267.86$ & $6,954.87$ \\
108 & $3,630.95$ & $3,587.00$ & $1,030.00$ & $3,267.86$ & $5,824.86$ \\
\hline
\end{tabular}


Table 6 Estimation of the average loss, per hectare, for the insurance company and for the farmer according to his forest area

\begin{tabular}{lccrrrrrr}
\hline & & \multicolumn{6}{c}{ FR for farmer, per ha, for different farm sizes } \\
\cline { 4 - 9 } Age $(t)$ & FSEV $(t)$ & FRI per ha & $<20$ & $20-40$ & $40-60$ & $60-80$ & $80-100$ & $>100$ \\
\hline 0 & $3,267.86$ & 17.65 & 3.92 & 7.84 & 8.99 & 9.15 & 8.82 & 1.80 \\
12 & $7,044.04$ & 38.04 & 8.45 & 16.91 & 19.37 & 19.72 & 19.02 & 3.87 \\
24 & $10,333.29$ & 55.8 & 12.40 & 24.80 & 28.42 & 28.93 & 27.90 & 5.68 \\
36 & $13,417.00$ & 72.45 & 16.10 & 32.20 & 36.90 & 37.57 & 36.23 & 7.38 \\
48 & $10,374.65$ & 56.02 & 12.45 & 24.90 & 28.53 & 29.05 & 28.01 & 5.71 \\
60 & $10,898.41$ & 58.85 & 13.08 & 26.16 & 29.97 & 30.52 & 29.43 & 5.99 \\
72 & $11,294.14$ & 60.99 & 13.55 & 27.11 & 31.06 & 31.62 & 30.49 & 6.21 \\
84 & $7,501.22$ & 40.51 & 9.00 & 18.00 & 20.63 & 21.00 & 20.25 & 4.13 \\
96 & $6,954.87$ & 37.56 & 8.35 & 16.69 & 19.13 & 19.47 & 18.78 & 3.83 \\
108 & $5,824.86$ & 31.45 & 6.99 & 13.98 & 16.02 & 16.31 & 15.73 & 3.20 \\
\hline
\end{tabular}

\section{Conclusions}

This study allows us to take the following conclusions. On the one hand, if there exits historical disaggregated data of fire events, for a region (municipality or other territorial unit) and for different sorts of trees, it is possible to build simple and precise models that allow estimating the probability of fire occurrences. The model accuracy will increase with the desegregation degree and with introduction of variables that take into account: combustion parameters, inflammable material, slope, proximity to the road network and urban areas, distance from water sources and management conditions of forest systems (Petrakis et al., 2005).

On the other hand, the forest stands expectation value for insurance purposes, for each species, can be obtained from governmental services, universities and research centres.

Finally, if forest fire insurance is compulsory, the insurance companies can divide the loss caused by fire events among a large number of farmers. Additionally, it can also be a way for governments to promote forest investments by paying part of farmer's forest IPs.

Therefore, it does not seem difficult to change the present conditions that make very difficult to find an insurance company that is willing to make a forest farm insurance. If this situation changes, a forest farmer, like any others entrepreneur, would share the risk fire by paying fair IPs. This will make forest investment less risky and so more attractive.

In short, this work shows that a single forest farmer with a small forest will not be able to pay a reasonable IP unless a large forest area is insured, which enables an insurer to cover his particular risk. To change this state of affairs, governments have to make forest fire insurance compulsory and research has to be done to find simple models to estimate, as accurately as possible, fire events probabilities and to calculate FSEV at different ages. 


\section{Acknowledgements}

The authors gratefully acknowledge two anonymous referees for their constructive comments and suggestions that were important in improving this paper. The authors gratefully acknowledge Dr Cláudia Gomes Portela for the English revision of the text and the suggestions to improve its readability. This work was funded by the project ALTERCEXA 'Medidas de Adaptación y Mitigación al Cambio Climático a través del impulso de las Energías Alternativas en Centro, Extremadura y Alentejo'. This work was developed with the support of Institute of Mediterranean Agrarian and Environmental Sciences of University of Évora (ICAAM) and the Department of Economics of University of Évora.

\section{References}

Campos, P. and Caparrós, A. (2006) 'Social and private total Hicksian incomes of multiple use forests in Spain', Ecological Economics, Vol. 57, pp.545-557.

Campos, P., Rodríguez, Y. and Caparrós, A. (2001) 'Towards the dehesa total income accounting: theory and operative Monfragüe study cases', in P.C. Palacin (Ed.), Special Issue-Investigación Agraria: Sistemas y Recorsos Forestales-Towards the New Forestlands Commercial and Environmental Benefits Accounting, Theories and Applications, Vol. 1, pp.43-67.

Cipra, T. (1994) Actuals Mathemetics in Practice. Prague: HZ Publishing Company.

Coelho, I.S. (2003) 'Propriedade da Terra e Política Florestal em Portugal', Silva Lus., Vol. 11, No. 2, pp.185-199, ISSN 0870-6352.

Cummine, A. (2000) 'Plantation insurance: an introduction', National Policy Director, Australian Forest Growers; Vic DNRE Seminar series, Financing Farm Forestry, May 2000.

De Saint-Vincent, R. (2000) 'R. De Saint-Vincent, Assurances des biens forestiers et gestion financière des risqués aux forêts', in S. Drouineau et al. (Eds.), Expertise collective sur les tempêtes, la sensibilité des forestset sur leur reconstitution. Dossiers de l'environment de l'INRA 20, forêts et tempête. Paris: INRA, pp.229-237.

DGF-IFN (2001) Distribuição das florestas em Portugal Continental: $3^{a}$ Revisão do Inventário Florestal Nacional (1995-2000). Lisboa: Divisão de Inventário e Estatísticas Florestais, Direcção Geral das Florestas.

Díaz, M., Campos, P. and Pulido, F.J. (1997) 'The Spanish dehesas: a diversity in land-use andwildlife', in D.J. Pain and M.W. Pienkowski (Eds.), Farming and Birds in Europe. The Common Agricultural Policy and its Implications for Bird Conservation. London, UK: Academic Press, pp.178-209.

Goldammer, J.G. (2004) 'International cooperation in wildland fire management', FAO Corporate Document Repository Unasylva, Vol. 55, pp.3-9, ISSN 0041-6436.

Holecy, J. and Hanewinkel, M. (2004) 'A forest management risk insurance model and its application to coniferous stands in southwest Germany', Forest Policy and Economics, Vol. 8, No. 2, pp.161-174.

Naveh, Z. (2007) Transdisciplinary Challenges in Landscape Ecology and Restoration Ecology - An Anthorology. Landscape Series. New York, NY: Springer-Verlag, ISBN 1-40204420-8.

Petrakis, M., Psiloglou, B., Lianou, M., Keramitsoglou, I. and Cartalis, C. (2005) 'Evaluation of forest fire risk and fire extinction difficulty at the mountainous park of Vikos-Aoos, Northern Greece: use of remote sensing and GIS techniques', Int. J. Sustainable Society, Vol. 5, No. 1, pp.50-65. 
Pinheiro, A.C., Ribeiro, N.A., Surový, P. and Ferreira, A.G. (2008) 'Economic implications of different cork oak forest management systems', Int. J. Sustainable Society, Vol. I, No. 2, pp.149-157.

Ribeiro, N.A., Dias, S., Surový, P., Gonçalves, A.C., Ferreira, A.G. and Oliveira, A.C. (2004) 'The importance of crown cover on the sustainability of cork oak stands: a simulation approach', in A.G. Ferreira and S. Schnabel (Eds.), Advances in Geoecology, Vol. 37, pp.275-286.

Ribeiro, N.A., Surovy, P. and Oliveira, A.C. (2006) 'Modeling cork oak production in Portugal', in H. Hasenauer (Ed.), Sustainable Forest Management Growth Models for Europe. Berlin, Heidelberg: Springer-Verlag, pp.285-313.

Shepard, H.B. (1935) 'Forest fire insurance in the Pacific coast states', Journal of Forestry, Vol. 33, No. 2, pp.111-116.

UNECE-FAO (2002) 'Forest fire statistics 1999-2001', Timber Bulletin, Vol. LV, No. 4, ECE/TIM/BULL/2002/4, New York, Geneva. Available at: http://www.unece.org/ timber/ff-stats/99-01/99-01.xls.

\section{Note}

${ }^{1}$ Mediterranean Cork Oak Forest Programme, Available at: http://www.panda.org/about_wwf/ where_we_work/project/projects/index.cfm?uProjectID=9E072. 